\title{
The idolatry of white supremacy in church and society? Some reflections on Black Theology of Liberation in present-day South Africa in memoriam of Vuyani Vellem
}

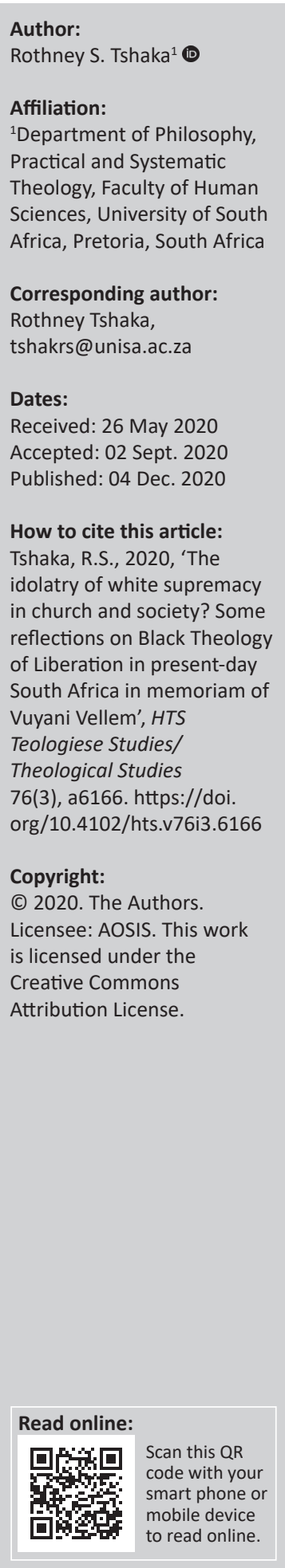

In remembering Vuyani Vellem, this paper delves into his scholarship, a scholarship that admittedly exudes his activism in academia, church and society. Choosing intentionally the marginalised as the primary interlocutors in discourse, Vellem demonstrates that he is situated in the arena of those who are otherwise seen as the wretched of the earth, insisting that Black Theology of Liberation must engage in a praxis that centres the lived experiences of black people and creates for itself legacies that would attest to Black Theology of Liberation as a formidable hermeneutic that recognises the sanctity of black life in a context of the prevalence of white supremacy. It notes however that a history of colonisation and subjugation has wrecked the humanity of black people, and as a result, a contract with black people becomes essential on this path towards the total emancipation of black people in South Africa and the world.

Contribution: The scholarly contribution of this article is its focus on the systematic and practical reflection, within a paradigm in which the intersection of religious studies, social sciences and humanities generate an interdisciplinary contested discourse.

Keywords: Vuyani Vellem; white supremacy; Black Theology of Liberation; Malcolm X; James Cone.

\section{Introduction}

The untimely death of Vuyani Vellem has left a devastating void in Black Theology of Liberation (BTL) circles, locally and internationally. Known for his profundity and knowledge in theology, Vellem has made a great impact in church, society and the academic world, not escaping the ire of white supremacy, which controlled and still controls society today. In theological spaces reserved mostly for white people, Vellem's presence was that of a towering giant, carefully analysing the matrices of empire in a supposedly, post-apartheid South Africa. This essay is an attempt at remembering a student of BTL who remained faithful to the most wretched of the South African and the marginalised of the world. Whilst the issue of material conditionality of black people never remained a distant feature in his theological reflections, Vuyani Vellem understood more than any of his peers that the real onslaught against black people has to be understood spiritually as well.

Occupying the position of director for the Center of Public Theology, Vellem continued to insist that BTL remain a theological hermeneutic, which was able to help black people consistently respond in a meaningful manner to their man-made conditions of exploitation and abuse. Therefore, Vellem remained un-bemused by the invention of new notions purportedly meant to augment the discourse that affected the most marginalised in South Africa today. By remembering Vellem, my intention in this essay is to allow his words to speak for him as he boldly always did in matters that remained very close to his heart.

One of the vexing challenges that Vellem had was the perennial call for BTL to be taken seriously. Admitting that this theological hermeneutic would never be recognised for the genius that it was, especially to black people, Vellem raised BTL to a level that insisted that black praxis be the order of business for theological reflection at least in South Africa. Firstly, he recognised more than anyone else, that in this call, black people remain undivided as far as the challenges that gang up on them are concerned. Secondly, Vellem realised that the struggle faced by black people in

Note: Special Collection entitled VukaniBantuTsohangBatho - Spirituality of Black Liberation, sub-edited by Fundiswa Kobo (UNISA) and Rothney Tshaka (UNISA). 
South Africa and the world, in general, is more than the mere material struggle and is in fact a spiritual struggle. For him, it is the spirituality of white supremacy that made the recalcitrance of whiteness such an enduring feature. Finally, it was significant that in an attempt to challenge the white supremacy's obduracy, black people should be awakened from their lethargic sleep, realising that their emancipation will come from no one else but themselves.

\section{The perpetual struggle for recognition}

John Henrik Clarke (1998) in his book, Christopher Columbus and the Afrikan Holocaust, argues that:

$[P]$ ortugal, which had initiated the movement of international expansion, claimed the new territories on the ground that they fell within the scope of the papal bull of 1455, authorizing her to reduce to servitude all infidel peoples. (p. 65)

Such reduction of the 'infidel people' to servitude was justified on many fronts. Amongst other things, this reduction was premised on the belief that black people in particular are not fully human, and this became the rallying point for the cause of the unjust wars of conquest (ed. Ramose 2013:7). That the pseudo belief in the inherent sub-humanity of black people was pervasive is an indubitable fact as evidenced in the racism of some of the Western World's most formidable scholars (Eze 1997). ${ }^{1}$

As a result, the African continent has suffered unmeasurable harm. The racism of the West created the impression that it [the West] ought to be the voice for the 'perpetual children of Africa'. The designation 'West' is problematic as Kofi Asare Opoku observes. Consider Opoku's (1996) views on this notion as he writes movingly:

[I] $\mathrm{t}$ is difficult to give a precise definition to the term 'the West' or 'Western', since those who apply it to themselves use it to connote a variety of ideas, ranging from European, white, Christian, capitalistic, democratic, progressive, modern, to even what is human. All these notions, however imprecise, have crystallized into a consciousness which understands itself to be different from all others, and views itself as the standard of value. Whatever is not rooted in this particular consciousness is not regarded as of equal value and may be taken to be backward, or retarded. And yet, paradoxically, the West, which is the youngest of all the cultures in the history of the world, has wrestled with this harm on many levels. Its antecedents in the non-Western cultures, which it tends to downgrade, and many of the values which have come to be accepted as noble and sublime have their sources in some of the older cultures of the world. (p. 83)

It was because of this mental temperament that these occidentals insisted on speaking for Africans in all aspects and disciplines. In 1977, at a Pan-African Conference of Third World Theologians held in Ghana, African theologians had concluded that they had had enough of this infantile treatment meted out against them by the West in theological conversations and that it is was their resolve to speak for Hegel, David Hume, Immanuel Kant and others, see Eze (1997). themselves. Kofi Appiah-Kubi (1981), in the preface of the book that contained the proceedings of the Pan-African Conference, summarised the underlining resolve of the conference when she averred:

'How can I sing the Lord's song in a strange land,' in a strange language, in a strange thought, in a strange ideology? (cf. Ps. 137:4) For more than a decade now the cry of the psalmist has been the cry of many African Christians. We demand to serve the Lord in our own terms and without being turned into EuroAmerican or Semitic bastards before we do so. That the gospel has come to remain in Africa cannot be denied, but now our theological reflections must be addressed to the real contextual African situations. Our question must not be what Karl Barth, Karl Rahner, or any other Karl has to say, but rather what God would have us do in our living concrete condition. (p. viii)

A Theological reflection that insisted on the primacy of the black situation in South Africa came about because of that resolve of Africa to speak for itself. Yet, it was not to happen without significant challenges from the hegemonic forces of the theology of the time. The birth of BTL as theological hermeneutics that was transplanted to this country from the USA was in a direct way, activated as a response to the white hegemonic theology that refused to recant its racism.

It has been recorded elsewhere that Black Theology of Liberation (henceforth referred to as BTL) was fundamentally influenced by Malcolm X (Cone 2007). Some reference to Malcolm X (henceforth referred to only as Malcolm) and his particular context of struggle should suffice here. I postulate that the struggles faced by Vuyani Vellem and many other black scholars can be seen in the struggles of Malcolm. By advocating a position that affirms the conditionality of the oppressed black people as an impetus for the struggle for recognition, Malcolm was faced with challenges from both the hegemony and his own fellow black people; the latter affected him most significantly.

However, he understood that these challenges were a device used to disrupt the unity of black people against the hegemony that is responsible for their oppression. Malcolm's use of the concepts of field and house negroes must be seen in a proper context of the continuous divisions that are created amongst black people. Let us briefly consider the context of the speech dealing with the aforementioned concepts.

The Detroit Council for Human Rights announced in 1963 that it would have a northern Negro Leadership Conference on 09 and 10 November. The chairman of the council, Rev. C.L. Franklin, decided to exclude black nationalists and Freedom Now Party advocates from attending the conference. The decision angered Rev. Albert Cleage Jr, who resigned his membership from the council in retaliation (ed. Breitman 2010:15). Malcolm's speech, entitled Message to the Grassroots, was given in the context of what happened during the approach to the leadership conference. For Malcolm, the fact that black people 'catch hell' primarily because of the colour of their skin and not because of their religious affiliation needed to be reassessed so that the 
power of unity amongst black people could be harnessed for the total liberation of black people in the USA (Malcolm $X$ in ed. Breitman 2010:17).

The biggest challenge that Malcolm observed in the said speech is what I would like to call the Willie Lynch syndrome ${ }^{2}$ amongst black people. Malcolm writes:

To understand this, you have to go back to what the young brother ... referred to as the house Negro and the field Negro back during slavery. There were two kinds of slaves the house Negro and the field Negro. The house Negro - they lived in the house with the master, they dressed well, they ate good because they [had] the leftovers of the master. They lived in the attic or the basement, still they lived near the master and they loved the master more than the master loved himself. They would give their life to safe the master's house - quicker than the master would. If the master said, 'we got a good house', the house Negro would say, 'yeah, we got a good house here'. Whenever the master said 'we', he said 'we'. That is how you tell a house Negro ... And if you came to the house Negro and said, 'Lets run away, lets escape, lets separate', the house Negro would look at you and say, 'Man, you crazy. What you mean, separate? Where is there a better house than this.' (Malcolm X in ed. Breitman 2010:22)

Malcolm was very much aware of the fact that, although it was the practice amongst slaves during slavery, the internalisation of slavery by black people had nonetheless evolved with time. The same attitude is seen in modern-day house negroes. On entering their masters' houses, these slaved Africans find for themselves a role to play and convince themselves of their significance for sustenance of the status quo. These are the very ones who become the spokespeople for the status quo and snitch on the black people who are restricted to the field because they exhibit signs of irreconcilability with the oppressive hegemony.

This tension, which is brought about in the interest of serving the hegemony, has origins in black self-hatred. When commenting on this praxis, Opoku (2012) argues that:

$[T]$ his praxis of self-hatred is part of a larger problem that faces people who have experienced oppression and who tend to internalize their subjugation and believe the preconceptions and stereotypes held about them by those who oppress them. Such beliefs certainly stunt their self-advancement and regeneration, and further entrench them in their subjugation. (p. 143)

In BTL's quest for recognition, these tendencies of disregarding those who are perceived to be militant have prevented this theological hermeneutic to percolate both academia and church today. Vellem was not oblivious to this challenge. For this reason, in engaging the notion of interlocution, Vellem (2012) argued:

2.Willie Lynch was a slave owner who mastered the art of inflating the differences between his slaves. He is known for having argued that the inflation of differences is the significance of the obsequiousness of black people. Lynch argued, 'On top of my list is age, but only list is age, but only because it starts with an 'a. The second is color or shade. There is intelligence, size, sex, sizes of plantation, status of plantation, attitude of owners, whether the slaves live in a valley or on a hill ... Have fair hair, coarse hair, or is tall or short. Now that you have a list of differences ... I shall assure you that distrust is stronger than trust and envy, stronger than adulation, respect or admiration. The black slaves after receiving this indoctrination shall carry on and will become self-refueling and self-generating for hundreds of years maybe thousands' (Lynch 2009:7f).
[T] he notion of 'Objective Blackness' must always be remembered as not implying that every black person can be an interlocutor of Black Theology of Liberation because there are several other categories to fulfill to be an interlocutor of this theology. (p. 3)

The notion of interlocution is rather significant in the reflections of Vellem. We shall have cause to return to this notion later in this essay.

Because BTL insisted that the lived experiences of black people ought to be taken seriously in theological reflection, it was never accepted into the mainstream of theological considerations in society. As such, it has attracted all sorts of derogatory musings in the minds of those who continue to benefit from a theology that deliberately disregards the material conditions of black people in this country. The main reason for making BTL a caricature is for the deterrence it takes hold in black communities in the country and elsewhere. But this was to be expected if one considers the deliberate positionality that BTL assumed. Again, let us hear Vellem speak on this.

\section{Vellem (2012) avows:}

[I]n other words, the choice of an interlocutor is a key to distinguishing one form of theology from the other. Black Theology of liberation has distinguished itself from Western orthodox theology by choosing the 'non-person' as its interlocutor, different from the 'non-believer' that has been the interlocutor of orthodox Western theology that undoubtedly remains part of the problem in South Africa post 1994. (p. 2)

In fact, Vellem here is not alone. Dwight Hopkins agrees with the sentiment when it comes to the preferential option for the poor. He writes, 'To prefer a specific option for working people and growing communities sinking into a system of poverty puts love of neighbor above private accumulation of things' (Hopkins 2002:53).

Recognising the specific stance that BTL adopts as it engages with hegemony, it becomes urgent for this theological hermeneutic to acknowledge the matrices of white supremacy that stare it in the face. It is thus significant in the reasoning of Vellem that white supremacy is called out for what it is. Vellem realises that this is a notion that seems to offend those that profit from it. Yet, white supremacy is kept intact by a spirituality that continues to disrupt black lives.

\section{The struggle against white supremacy as a spiritual struggle}

The Curriculum Transformation Framework of the College of Human Sciences, University of South Africa, defines white supremacy as follows:

[T] he juridical, socio-economic, educational and political order which is assembled and exists globally on the basis of Eurocentrism. White Supremacy first and foremost produces superior life chances for those born of European heritage, longer life expectancies and a higher quality of life. It privileges white modes of life, languages, cultural norms and practices, laws, value systems and at the same time derogates and lowers the 
biological lives and life expectancies of 'non-whites' and 'nonwhite' cultures, laws, practices, etc. ${ }^{3}$ (Mazrui 1978:285)

The character of this definition comes very close to the observation made by Ali Mazrui about the idea of a university in Africa. Mazrui (1978) reminds us that ' $[a]$ lmost all African universities in the colonies started as overseas extensions of metropolitan institutions in Europe' (p. 285).

\section{Moraña, Dussel and Jáuregui (2008) insist that:}

[T] he critique of Occidentalism - that is, of the philosophical, political and cultural paradigms that emerge from and are imbedded in the historical phenomenon of European colonization - is essential to the understanding of the aggressive strategies used in imposing material and symbolic domination on vast territories in the name of universal reason, as well as of the opposition this domination generated over the centuries in 'New World' societies. (p. 2)

Realising the urgency of this critique as outlined by Moraña, Dussel and Jáuregui, it was not enough for Vellem simply to use the notion racism in his struggle against hegemonic white theology in post-apartheid South Africa. He is of the view that the problem needed to be defined properly so that BTL would be able to frankly engage with the identified problem. Piggybacking on James Cone, who averred that white supremacy was America's original sin (Cone 2018:18), Vellem too insisted that this was the case for white supremacy in the world and specifically in South Africa. Thus, for him, BTL was confronted with white supremacy and, as such, needed to prepare itself to engage with it, with the same enthusiasm that white supremacy is inflicting pandemonium on black lives (Vellem 2018b).

This positionality is very close to the one adopted by James Cone. For instance, Cone (2018) argues in his book Said I Wasn't Gonna Tell Nobody that:

$[V]$ iolence is not black people's primary response to white supremacy, but self-defence is important for black dignity. The ever-present violence of white supremacy - psychic, physical and spiritual - in the black community should be the chief concern of white Americans. Reconciliation is a white responsibility. (p. 47)

It is for this very reason that I use white supremacy, aligning myself with both Vellem and Cone and agreeing that white supremacy better encapsulates the challenge that BTL is confronted with today.

In my view, Vuyani Vellem must be considered one of the most vociferous theologians that democratic South Africa has ever seen, an astute academic whose heart was undoubtedly located amongst the grassroots people of South Africa. He was unwavering in his belief that the struggle that is waged by white supremacy against black

3.The Curriculum Transformation Framework of the College of Human Sciences is a discussion document meant to facilitate a conversation on how transformation should be mapped out in the said college. It contains, amongst other issues, a glossary of terms that need to be engaged with for a frank discourse on how the glossary of terms that need to be engaged with for a frank discourse on how the
college moves ahead in championing a curriculum that is truly African in both college moves ahead
content and outlook. people in South Africa was essentially a spiritual struggle. His agitation against white hegemony could be felt in church, society and especially in academic circles. Recently, with the challenge brought about by the \#FeesMustFall, \#RhodesMustFall, Vuyani Vellem was not an armchair supporter of the aforementioned grassroots movements but was centrally located in the struggle and agitated alongside students against hegemony (Vellem 2018a:5, 2018b:518). ${ }^{4}$

This was so because Vellem realised that the struggle is essentially one that is spiritual. I must hasten to add that Vellem's understanding of the spiritual is not the one promoted by Western orthodoxy of the binary between the material and the spiritual. In fact, seen through the prism of spirituality, Vellem is able to understand what moves racism in a country that had allowed the status quo to remain unmoved at the expense of the oppressed black people of South Africa.

By lifting the veil of spirituality and illustrating how ideology undergirds faith, Vellem (2018b:521) reaches across a sterile spirituality that Africans had been encouraged to embrace to the detriment of the material circumstances they occupy. Vellem is not alone in dissecting the matrices of a colonial spirituality that profited on black struggle.

Opoku (2018) is in agreement with Vellem when he declares:

[W] hat scholars call 'religion' is not a separate category in African societies, but part and parcel of their culture which, in addition to their social structure, is infused with a spirituality that cannot not be separated from life in community. (p. 5)

Gustavo Gutierrez (1985:37) puts it in a similar manner when he avows that 'at the root of every spirituality there is a particular experience that is had by concrete persons living at a particular time'. The fact that ideology undergirds faith is indisputable. Vellem (2018b) explicates on this assertion:

$[W]$ ith ideology we can tell our stories and relate to our existence, even grasp the contestations that exist among us, the forms of exploitation and our modes of struggle for life. Ideology offers a vision of what is possible; it is as inspirational, and on its basis we are guided ethically, we are able to choose between right and wrong, good and bad, and ultimately, we are guided by ideology to legitimize power and the ethos of our lived experiences. Admittedly, ideology can exist independently much as faith can do; however, dangerous ideology is a permanent danger to faith, and faith without ideology is as toxic and tragic. (p. 522)

4.I had a number of frequent conversations with vellem on a plethora of subjects mostly associated with those on the underside of life. That Vellem would be involved in the \#FeesMustFall movement would be obvious given his propinquity to the marginalised. In a conversation with a former PhD student of Vellem regarding her Doktovater's views and involvement with the \#FeesMustFall movement, Dr Fundiswa Kobo reminded me that Vellem was not only intellectually involved with the movement, but in fact, he was intellectually and physically in police stations for students of the University of Pretoria, who were charged by the university for their students of the University of Pretoria, who were charged by the university for their involvement in the movement (WhatsApp message: 26 May 2020). Vellem had also relayed to me a disturbing feeling that his involvement with the \#FeesMustFall might have perturbed those within the powerful positions of the university. This was so because he had observed, on more than one occasion, break-in attempts into his office at the Faculty of Theology at the University of Pretoria. At the time of his death, Vellem was considering sharing some of his experiences that emanated from his involvement with \#FeesMustFall and linking it to an idolatrous spirituality of white supremacy. 
To speak about the spiritual in a context where the mentioned phenomenon had been abused and is relegated to the back because it is perceived to be devoid of import in a world where the hard sciences are preferred, seems to be a challenge to theology. Thus, spirituality is raised by Vellem in a context where there seems to be an increasing sense that theology has become obsolete precisely because it ignores the spiritual element in her reflections today. Even those who engage in BTL today seem to be engaging in it more through a mixed, inter- or trans-disciplinary approach; what is challenging here is that theology in most cases seems to be lost in the process. Whilst there is no harm in doing so, there clearly remain challenges for theology as an independent discipline.

Black Theology of Liberation's struggle to be heard is now a long-standing struggle. In fact, there is an emergent school of thought that suggests that BTL ought to give up its apologetic demeanour and focus radically on the issues that it confesses in order to generate faster embodiment of those very issues. Whilst it emerged on South African soil as a hermeneutic that remained suspicious of the dominant hegemonic theology, for the purpose of this article, I would like to punctuate the vitality of the white hegemony in hiring out from the leadership of the black people's liberation projects. Hiring out from the masses was not enough.

Hopkins (2002:160) had warned against this propensity when he pled that apologists of BTL are vigilant of the dangers in the castle of the mainstream. Black Theology of Liberation faced an onslaught when, with the arrival of the democratic dispensation, some of her key proponents became guests in the castles of hegemonies in South Africa, thereby killing the verve of BTL's agency. It goes without saying that this vigilance was not observed enough, and this lack of observance has allowed proponents of the dominant white theology to scoff at the relevance of BTL in a democratic milieu. This was evident in the pronouncement of the death of BTL. This pronouncement came not from black people themselves but rather from those liberal white people who continued to view BTL as passé in a democratic South Africa.

Vellem could not contain his disgust at the flagrant display of white hubris when the unsolicited pronouncement of the death of black theology was made. In an interview for the Acta Theologica Journal, Vellem (2018a) recounts his disturbance at an important conference on mapping theology in a post-apartheid South Africa. He writes:

[F]or example, one vividly remembers even one of the exponents of the school at the University of Cape Town in 1999 publicly declaring the death of BTL in one of the biggest international conferences I witnessed as a student then, the Multi-Event 1999. There have both been internal and external attacks on the standing of BTL, even at the earliest times of its development. (p. 2)

Vellem adopts this position out of irritation really. In another paper published in 2010, he critiques Villa-Vicencio's proposed project of reconstruction. Vellem sees such a proposal as a camouflage of a dangerous ideology that presents itself as innocuous to the South African public, who is yet to make sense of the negotiated settlement called the New South Africa. Vellem (2010a) writes:

$[T]$ o assert that Black theology of liberation, which has been discounted as moribund after the demise of apartheid, is not only a potential kind of public theology but, also, a public theology among others, unveils the ideological ramifications of the proposal for reconstruction. (pp. 547-548)

No doubt, the preoccupation to want to speak for black people as if they are the perpetual students, whilst white people are the perpetual teachers, is a vexing problem that persists even today. It is this attitude, which to me, is suggestive of the frustration that let Livingston Mqotsi to dub the gatekeepers of academia the 'witches of academia' (Bank 2013:242).

\section{The squalor of zinc forests as evidence of the idolatry of white supremacy}

It is a matter for concern for black theological reflection today that not much was made within the academic spaces to ensure that BTL, as a science that took the marginality of black people seriously in Africa, could percolate academia. The idea of giving up 'shop talking' about BTL and focusing on the praxis of BTL has to do with an apparent obsession that BTL used to have with whiteness.

The fact that BTL came about as a result of white supremacy is undeniable and cannot be wished away; yet, what is needed today is a deliberate move to push BTL's agenda to the many challenges that confront the black situation today. This is one of the reasons why Vellem (2017:1-7) shifted his focus to the unthinking of the West in engaging with burning issues that affect the communities of the most marginalised in society today. At the centre of this reasoning was of course the question of faith: to move from a faith that disempowers, to one that galvanises the African into action.

The disparities in the quality of life between white and black people in the world, and particularly in South Africa, were never something that was ordained by God but was in fact a synthetic creation that calls for enlightened and liberated black people to question that formation perpetually. This is evident in the work that Vellem embarked upon in black communities as indicated especially in his later writings.

The Bible and Theology from the Underside of Empire, which he co-edited with Sheerattan-Bisnauth and Peacock on behalf of the Council for World Missions, illustrates the significance of the reflection with those on the underside of the empire for Vellem (eds. Vellem, Sheerattan-Bisnauth \& Peacock 2016). What he refers to as the 'zinc forests', which are a hallmark in most major metropolises around South Africa, are places of struggle, and therefore, any relevant 
theology ought to be able to take these communities seriously in reflection (Vellem 2018b:519). Again, the idea of interlocution comes to mind here. Who are our conversational partners? Who speaks and for whom? Who informs the questions for theological reflections on the margins?

The notion of ekassie is one that deliberately brings the focus of life on the margins to the centre of theological reflection. Greatly influenced by James Cone's engagement with the ghetto in the USA and how it is appropriated by black people when interpreting the cross, Vellem (2018b) sees ekassie through the prism of the cross. Vellem (2018b) explains this phenomenon thus:

[T] he name ekassie itself is fascinating if one thinks about the reality of squalor, the growing 'zinc forest' of informal settlements, rows and columns of corrugated iron structures in every major city in South Africa post-1994. (p. 519f.)

If ekassie is that detestable locale, what is equally repugnant is the Mekhukhu that characterise the mentioned locality. A large number of people that occupy such spaces belong to the socalled African Initiated Churches (AICs). Vellem (2010c) argues that:

[T] he text of the AICs is present through a spectacle of sordid and squalid conditions signified by a Mokhukhu (shelter) on the peripheries of our cities even after the demise of Apartheid. (pp. 1-6)

A Mokhukhu (Mekhukhu, plural) may be known to Africans as a shelter made of corrugated iron, plastics, wood and practically everything one can find.

With regard to the Mekhukhu as places of worship, Vellem sees in them something more than mere corrugated iron shacks. He agrees that 'for many Black people, Mokhukhu signifies landlessness, socio-political deprivation, social psychosis and exclusion of millions who also dwell in these structures' (Vellem 2010c:1-6). Township life is no doubt ambivalent, an absolute inconsistency. For Vellem, the locale of ekassie is likened to the cross of Jesus. It is 'unutterably ugly and cruel, an instrument of the Roman Empire used to condemn Jesus, but with something, paradoxically, good coming out of it in our Christian faith' (Vellem 2018b:520).

It is however the ability of black people to subvert the cross, thereby making it into something it was not intended to be, which encourages Vellem. It is this black subversion that permits Vellem to be continually interested in a theology from the underside of society. A theology that subverts a hegemonic theological reflection of the present society must be encouraged because it reflects a cruel establishment. This cruelty is expressive in the concomitant foulness that comes with the creation of diverse locales, created with racial justification. But more importantly, this subversion must be encouraged because it is intended to deflate the inherent powers of the continued lynching of black bodies until further notice; for Black Theology of Liberation, subversion was an indefatigable attempt at circumventing the status quo, thereby depriving it of its powers.

Vellem understood this very well and recognised that the main objective of white supremacy of wanting to stifle BTL was simply because, as a hermeneutic, it insisted radically that the context of black people ought to frame the questions for black people in South Africa. No doubt, BTL affirms the dignity of black people. Vellem (2010b) argues, for instance, that:

[I]sithunzi is a 'shade'. Isithunzi/Serithi is a vital life force and is immortal. Most importantly, Isithunzi is specifically about the connectivity of life, indeed a conviviality of spheres and forms of existence shaded by a vital force that bonds the whole of life. (p. 316)

Isithunzi in Isixhosa or Serithi in Sesotho words, respectively, that capture the essence of dignity. All are significant especially in understanding why ekassie is such a vile creation of white capitalist interests in South Africa. It is unfortunate that BTL itself did not insist more radically in considering the hoi polloi as significant conversational partners in the process of making sense of faith in a senseless context. Interlocution was thus significant in the reflections of Vellem because he realised the essence of who speaks and on whose behalf. One of the mistakes that BTL made was to accept its so-called middle-class position and bequeath the powers that it had. The idea of education in South Africa has a perverted consanguinity with Western Christianity. Archie Mafeje observed this tendency during his anthropological fieldwork in Langa. Mafeje (1975) avers:

[I]t is evident that Langa is pervaded by a Christian middle class ideology which denigrates paganism, and which places a premium on Christian education as a civilizing influence and a source of respectability. (p. 170)

The civilising parlance that the Christian education is seen to have continues to create tensions in ekassie. Yet, it is my contention that this ought to be seen within its historical setting. I shall in a moment return to this assertion.

The perception that suggests that education is synonymous with Christianity is one that continues to be recognised even within BTL circles. It is thus my opinion that this perverted view of determining what constitutes education in society informed the deliberate marginalisation of those affiliated with ATR as proper conversational partners. This would be the Achilles heel of BTL. Having dealt with the deliberate disregard for anything African by the west, one hopes that we can appreciate the mayhem in the attempts made at reconciling BTL and African theologies. It is indisputable that, from the very moment they were conceptualised, they were meant to mean different things in the minds of their apologists.

To return to my earlier promise regarding the historicity of categories in theological reflection, it must be remembered that those associated with ATRs are also treated by Africans 
themselves, as being somewhat backwards. Again, one must not forget the damning indictment that Mazrui made on the idea of a university in Africa as a transmission belt of new knowledge and new ideas between its own societies (Mazrui 1978:366). The fact that those associated with ATRs are seen as less and, therefore not worthy to be conversational partners in the space of proper theology is as a result of how African religious views have been caricatured by even some of the most serious stalwarts of the Western World. Again, consider the assertion by Mazrui (1978), who argued that 'western education in African conditions became a process of psychological deruralization. The educated African became in a fundamental sense a misfit in his own village' (p. 16). Okot P'Bitek reminds us that 'in the 19th century', Auguste Comte, the positivist philosopher, sketched a picture of development of the human mind through three stages:

- religious, from the beginning to the 4 th century

- metaphysical, from the 14 th to the 18 th century

- positive, the 19 th century.

P'Bitek notes that further subdivision into three periods of the religious stage, namely, fetishism, polytheism and monotheism, is significant. The apparent religion of African people falls into the stage of fetishism and is relegated to the bottom of the ladder ( $\mathrm{P}^{\prime}$ Bitek 2011:20).

When Vellem speaks of interlocution, there can be no doubt that the interlocution that he is imagining is an interlocution of those who remain on the periphery of society; those who are considered the scum of society by the way they are being treated. In a context where black people themselves can become drones that exploit the condition of the black people, it is ever necessary to establish who speaks, and for whom. As indicated, the divisions created by the West in Africa are ever-present.

Division here is reminiscent of the British colonial era of divide and rule. The divide and rule principle was a central principle of British imperial policy. It was a means of keeping different ethnic groups occupied with differences amongst themselves to prevent them from organising against their colonial masters. The same principle was quite widespread during apartheid in South Africa and continued into democratic South Africa. It serves the purpose of highlighting differences amongst groups to prevent them from seeing the real problem, which is colonialism.

Recognising the fact that, within the ranks of BTL, issues of class remain; thus, it would be naïve to assume that all black folks are actually for total and unconditional black emancipation. Vellem argues most forcefully for a BTL that ceases her obsession with whiteness. The fact that BTL did not realise early enough the essence of taking African worldviews seriously in its reflections is for me a clear example of BTL's own obsession with Eurocentrism as the most preferred form of life that must be emulated even to the detriment of African identity.
We see this fascination in many instances in society today. In theology, we see how the black oppressed uncritically adopt Eurocentric ideals, some of which are violent conquest celebrations of black peoples' lands and identities. Vellem had debunked these uncritical usurpations of Eurocentric positionalities when he critiqued, for instance, Te Deum Laudamus and translated into Isixhosa as Siyakudumisa. Seen in its historic context, Te Deum Laudamus is a doxology of Vasco da Gama's violent seizure of the city of Kilwa in Tanzania (Vellem 2019:73-74).

By reminding us of the historicity of this doxology and the violence against Africa and Africans to which the doxology pays homage, Vellem has illustrated that any attempt at giving voice to the church in Africa cannot be comfortable with the mere translation of Western liturgies into the indigenous languages of Africa. However, it is imperative to understand what is beyond that which we appropriate for Africa today. In fact, Kwesi Dickson (1984) had pointed to this challenge in his Theology in Africa. He wrote:

$[M]$ erely eliminating the Western cultural attachments could still leave the Church in Africa with a Christ who wears an unauthentic countenance. It is important to be able to identify those cultural elements from the west that came with Christianity as it has been presented, but the indigenization or Africanization policy that proceeds solely along these lines to the exclusion of all other possible approaches assumes, quite wrongly, that there can be a proclamation of the Gospel that does not have a cultural particularity. (p. 119)

To say that Vellem is asking for a BTL that is not fixated on whiteness is not at all to be confused with a perception that suggests that whiteness is not a problem. Quite the contrary, for him, whiteness as an Idee is the most preferred form of being human today in the world, which is an all-pervasive phenomenon. It erects itself on to the spaces of black bodies, irrespective of whether it is invited. I use the word 'erect' here in the most vulgar sense of the word. This suggests that there is no regard at all for that which whiteness has objectified as garbage. The fact that whiteness is vital in the reflections of those who subscribe to BTL, is intentional.

Consequently, a BTL that is not fixated on whiteness does not suggest the subject of whiteness and is not to be questioned. It is rather Vellem's realisation that such fixation with whiteness precludes black people from seeing and gleaning valuable insights from their African selves, past and present. This galvanises him into accentuating African spiritualities as the force that makes Africans be content with and in their black bodies. White supremacy's erection into black spaces has created zinc forests that have become the epitome of nihilism. Yet, it is within these spaces, which are a reality for the majority, that survival is given meaning. Life thus becomes the art of survival in these black spaces.

\section{Conclusion}

The total emancipation of black people is contingent on black people's own efforts and will not fall from the sky. This is the 
guiding resolve of Vukani Bantu/Tsohang Batho. Vukani Bantu recognises that the struggle at hand is essentially a spiritual struggle. Vukani Bantu is no doubt the brainchild of Vellem. That he resolved to the formation of this movement, which essentially realises that the struggle is especially a spiritual struggle, was because Vellem admitted that our theological forebears had failed to create lasting legacies that unapologetically defended the sanctity of black lives in South Africa. Frustrated with the perpetual requests for acknowledgement in spaces that had rendered black lived experiences non-existent, Vellem finally devised Vukani Bantu as a conduit that would foreground the lived experiences of black people in society.

Vukani Bantu continues to create platforms in ekassie across South Africa with the intention of giving voice to the voiceless. It recognises that it is going to take a multi-pronged approach if we are going to be victorious. Nonetheless, unity amongst black people continues to be one of the greatest challenges in the struggle against the idolatry of white supremacy. The required unity ion the struggle against white supremacy, recognises that a covenant with black people requires not only a mere lip service but also a commitment to fight to the bitter end, irrespective of the many challenges that also come from black people themselves. It will take likeminded individual in the struggle for the recognition of the full humanity of black people to understand that to be associated with the majority of black people is to expect the adversities that will come with such an association.

\section{Acknowledgements Competing interests}

The author has declared that no competing interests exist.

\section{Author's contributions}

R.S.T. is the sole author of this research article.

\section{Ethical consideration}

This article followed all ethical standards for research without direct contact with human or animal subjects.

\section{Funding information}

This research received no specific grant from any funding agency in the public, commercial or not-for-profit sectors.

\section{Data availability statement}

Data sharing is not applicable to this article as no new data were created or analysed in this study.

\section{Disclaimer}

The views and opinions expressed in this article are those of the author and do not necessarily reflect the official policy or position of any affiliated agency of the author.

\section{Reference}

Appiah-Kubi, K. \& Torres, S. (eds.), 1981, African theology en route, Orbis books, Maryknoll.

Bank, L.K., 2013, 'Witchcraft and the academy: Livingston Mqotsi, Monica Wilson \& the Middledrift Healers 1945-1957', in A. Bank \& L.J Bank (eds.), Inside African Anthropology: Monica Wilson and her interpreters, Cambridge University Press, Cambridge.

Breitman, G. (ed.), 2010, Malcolm X speaks, Pathfinder, New York, NY.

Clarke, J.H., 1998, Christopher Columbus and the Afrikan holocaust: Slavery and the rise of European capitalism, Eworld Inc., New York.

Cone, J.H., 2007, Martin and Malcolm and America: A dream or a nightmare, Orbis, Maryknoll, New York, NY.

Cone, J.H., 2018, Said I wasn't gonna tell nobody: The making of a black theologian, Orbis Books, Maryknoll, New York, NY.

Dickson, K., 1984, Theology in Africa, Orbis Books, Maryknoll, New York, NY.

Eze, E.C. (ed.), 1997, Race and the enlightenment: A reader, Blackwell Publishing, Malden. Eze, E.C. (ed.), 2009, Race and the enlightenment: A reader, Blackwell Publishing, Malden. Gutierrez, G., 1985, We drink from our own wells: The spiritual journey of a people, Orbis Books, Maryknoll.

Hopkins, D., 2002, Heart and head: Black theology-Past, present and future, Palgrave, New York, NY.

Lynch, W., 2009, The Willie Lynch letter and the making of a slave, Classic Books America, New York, NY

Mafeje, A., 1975, 'Religion, class and ideology in South Africa', in M.G. Whisson (ed.), Religion and social change in Southern Africa: Anthropological essays in Honour of Monica Wilson, pp. 165-184, Rex Collings Ltd., Cape Town.

Mazrui, A.A., 1978, Political values and the educated class in Africa, Heinemann, London.

Moraña, M., Dussel, E. \& Jáuregui, C. (eds.), 2008, Coloniality at large: Latin America and the post-colonial debate, Duke University Press, Durham.

Opoku, K.A., 1996, 'The west through African eyes', International Journal of African Studies 4(1-2), 82-98.

Opoku, K.A., 2010, 'Cooking on two stones of the hearth? African spirituality and the socio-transformation of Africa', Journal of African Christian Thought 13(1), 3-9.

Opoku, K.A., 2012, 'Skinny but imperishable truth: African religious heritage and the regeneration of Africa', Studiae Historiae Ecclesiasficae 38 (suppl.), 141-151.

Opoku, K.A., 2018, 'The baobab tree of truth: Response to two papers on Barth and comparative theologies', Unpublished paper, p. 11.

P'Bitek, O., 2011, Decolonizing African religions: A short history of African religions in western scholarship, Diasporic Africa Press, New York, NY.

Ramose, M.B. (ed.), 2013, Hegel's twilight: Liber amicorum discipulorumque pro heinz kimmerle, Radopi, Amsterdam.

Vellem, V.S., 2010a, 'Prophetic theology in black theology, with special reference to the kairos document', HTS Teologiese Studies/Theological Studies 66(1), a800. https://doi.org/10.4102/hts.v66i1.800

Vellem, V.S., 2010b, 'Serithi/Isidima: Reflections on human dignity in South Africa from a Black African/Perspective', Scriptura 104, 314-321. https://doi. org/10.7833/104-0-173

Vellem, V.S., 2010c, 'Ideology and spirituality: A critique of Villa-Vicencio's project of reconstruction', Scriptura 105, 547-558. https://doi.org/10.7833/105-0-156

Vellem, V.S., 2012, 'Interlocution and black theology of liberation in the 21st century: A reflection', Studia Historiae Ecclesiasticae 38, 1-9.

Vellem, V.S., Sheerattan-Bisnauth, P. \& Peacock, P. (eds.), 2016, Bible and theology from the underside of empire, SUN Press, Stellenbosch.

Vellem, V.S., 2017, 'Un-thinking the West: The spirit of doing black theology of liberation in decolonial times', HTS Teologiese Studies/Theological Studies 73(3), 7. https://doi.org/10.4102/hts.v73i3.4737

Vellem, V.S., 2018a, 'Interview with Vuyani Vellem', Acta Theologica 38(1), 1-14. https://doi.org/10.18820/23099089/actat.v38i1.1

Vellem, V.S., 2018b, 'Spiritual dimension of embracing the cross', International Review of Missions 107(2), 515-530. https://doi.org/10.1111/irom.12247

Vellem, V.S., 2019, 'Imanyano, singing Siyakudumiza: Ambivalent worship and the reformed tradition in South Africa', St Augustine Papers 19(1-2), 73-99. 